ち流速の変化の度合と鼻咽腔の長さ, さらに呼吸回数の 頻度が悬咽腔圧に影響を与えていることを明示した。

啠問 白井信郎 (東邦大). われわれは鼻腔抵抗をだ す場合, Resiratory frequency, Tidalvolume む一緒に だし，さらに Flow を一定にした值で表現しているがど らか. また定常流の部分をとると，Flow が大きすぎて
比較に不都合をきたす場合もあるがどらか。応答 岩田重信 (名保衛大)。番内気流, 圧関係式の上から, 呼吸回数 $(w)$, 流速 $(v)$ 等任意の点に捛ける測定が可 能で, 被検者に特定条件をつけることは非生理的にな り，余り賛成しない

\title{
11. 音刺激による誘発反応漶波波形の構成周波数分布について
}

\section{○曾田豊二・加藤寿彦・山本哲生・調 重昭・松展正彦（福岡大）}

平均加算法に上る脳波聴検での判定の困難さの一つは 睡眠深度の各相, 脑発育, 被検児の状態などが混じり, 反応波形に複雑な影響を与えることである。一般に所謂 V-Pは睡眠樑度が梁くなつたり，年令が低くなれば peak 潜時注延長する傾向にある。これら誘発電位性音刺激に よつておこされる脳波上の擾乱々考えられ，原脳波それ 自身に，それ故その脳波を楧成する各周波数にも分析波 形的にみて影響があたえられていると考えられる。そし てこれは特に低周波域（10Hz 以下）汇影響が与えられ る.

しかも年令が低下し，また睡眠が哚くなればなるほど これよりもなお低、周波数帯域に影響が大きくあらわれ てくる傾向がある。この際低い周波数のらちある特定の 周波数帯域のみが影響をうけるのではなく, 大きく影響 をうけた周波数带域の近傍の周波数帯域も程度の差はあ れ影響をらける。すなわち連続細分狭帯域フィルタ(0.5 -0.8 . $0.5-1.0 .0 .8-1.2,1.01 .5,152-1.6,1.4-2.0$. $1.8-2.5,2.0-4.0,4.0-8.0,8.0-13.0 .13 .0-20.0 \mathrm{~Hz}$ 群や 1.0-1.5. 1.5-2.0,2.0-3.0. 3.04.0. 2.0-4.0. 4.0-8.0. 8.0-13.0群や1.8-2.5, 1.8-3.2,3.2-5.0. 5. $-7.1 \mathrm{~Hz}$ 群) を用い各フィルタに対する最大振幅部の変
動を測定した。これを観察すると成人覚醒時ではこれら のフィルタ群の最大值を得た 4.0-8.0 Hz を中心にした 左右の帯域でこれより小さな值をもつ分布型を得た。 drowsy, light sleep, asleep になるにつれてこのフィ ルタ群で得られた最大值は覚醒時の際より低い方の周波 数狭帯域側八移行した分布型を示した。 このよらな測定 結果は，無刺激時で得られた略平坦な分布型と対比して 反応波形判定の際判定を容易になると考えられ，また自 動処理のための一つの情報を提供するとも考えられる.

質問 市川銀一郎 (順大). 誘発反応, 聴力七经にお いて，どの籁囲のフィルターを使用するのが効果的か. 忘答 篔田豊二 (福岡大). 適切な連続細分フィルタ の带域幅を決めることが重要である，少くとも $0.5 \mathrm{~Hz}$ から $2 \mathrm{~Hz}$ 位までは $0.5 \mathrm{~Hz}$ ごと，それ以後は $2 \sim 3 \mathrm{~Hz}$ ごと 位に分けてみるとよいと思われる。但し $0.5 \mathrm{~Hz}$ 前淩のフ イル夕牥不安定さが伴うので，注意す心゙きである，

質問 鈴木篤郎（信大）. ERA の情報処理の一法 としてのFilter の使用の将来の見通しはどらか. 応 答 曾田豊二（福岡大）。この連続細分狭帯域フィルタ 方式は臨床的な自動処理を考える時 pattern 認知として 一つの情報を提供するものと思う。 